\title{
THE GENUS AMANITA (Pers.) IN LUMBINI ZONE, NEPAL
}

\author{
Hari Prasad Aryal* and Usha Budhathoki** \\ *Paklihawa Campus, Institute of Agriculture and Animal Science, Bhairahawa. \\ **Central Department of Botany, Tribhuvan University, Kirtipur, Kathmandu, Nepal.
}

\begin{abstract}
During the survey of wild edible mushrooms in tropical to temperate belt of Nepal during rainy seasons in 2010 and 2011, many macro fungal species were collected and identified. The paper highlights on the five species of genus Amanita Pers. including new species Amanita volvata (Peck) Lloyd with their identification and documentation. The new species was identified and this is being reported and re-described for the first time from Nepal. Amanita characterized by stipe with volva or rudiments of volva, annulus present, in some may be absent, clamp connection present or absent, spores amyloid or inamyloid. The study area occupied $0.55 \mathrm{sq} . \mathrm{km}$ among the $9.288 \mathrm{sq}$. Km land and lies within an altitude between 90 and 2500 masl in tropical deciduous riverine forest to lower temperate mixed broad-leaved forest. The dried specimens are housed in the Tribhuvan University Central Herbarium (TUCH), Kirtipur Kathmandu, Nepal. The area embraces many mycophagous ethnic communities. The mycoelements prevailing in this area need sustainable conservation and utilization.
\end{abstract}

Keywords: Tasonomy; Basidiomycetes; Amanita volvata; Macrofungi.

\section{INTRODUCTION}

The investigation and study on mushrooms of Nepal started since $19^{\text {th }}$ century (Lloyd, 1808; Berkeley, 1838). The genus Amanita contains over 500 named species and varieties (Adhikari et al., 2010). Amanita from Nepal has been reported since $20^{\text {th }}$ century (Singh, 1996ab), since then several papers have been published. 42 species and 2 subspecies of Amanita are reported from Nepal (Adhikari et al., 2010), since then several botanical investigations have been done. Among these, very few reveal the studies and investigation on wild mushrooms from western Nepal. This area has not been previously investigated so far. This is a preliminary report on highlight on; presently five taxa of the genus Amanita Pers. with the addition of new species from Lumbini zone a region of tropical to temperate monsoon climate and west-south region of Nepal. Amanita volvata (Peck) Lloyd was identified and this is being reported and re-described for the first time from Nepal have not reported previously been recorded. The new findings have published here.

\section{STUDY AREA}

The study area (fig.1) lies in Lumbini Zone, Partial parts of Paklihawa-Rupandehi (90m), Tikkar-Kapilwastu (222m), Ramnagar-Nawalparasi (256m), ThadaArghakhanchi (500m), Simaldanda-Palpa (900m) and

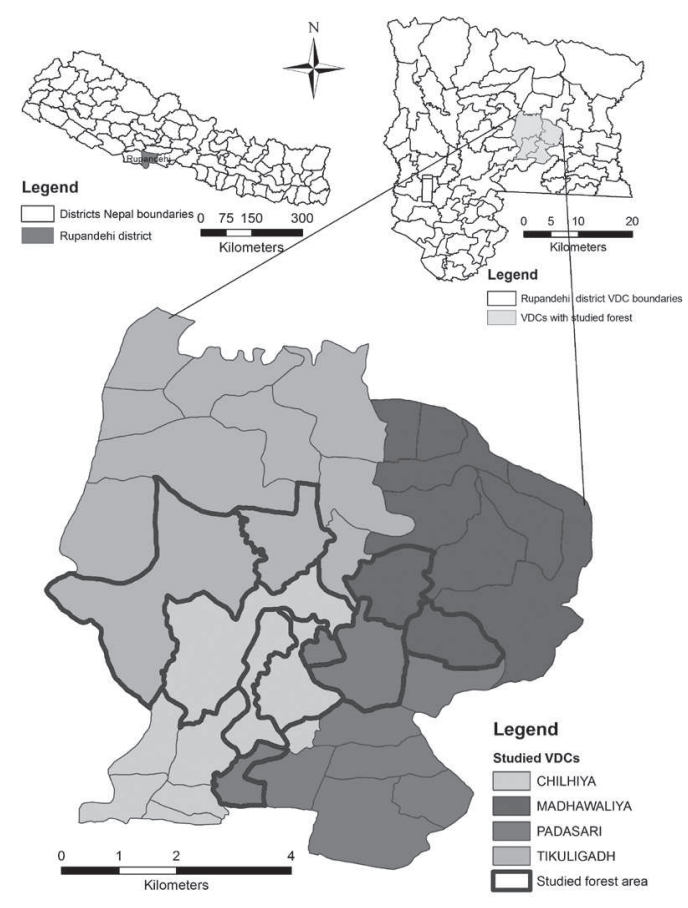

Figure 1: Sample Collection sites

Rsunga-Gulmi (2350m) of mid-west region of Nepal. It lies between $27.4813^{\circ}-28.13765^{\circ} \mathrm{N}$ latitude and $83.09029^{\circ}-84.05827^{\circ} \mathrm{E}$ longitude. The vegetation in forest is dominated by members of the Combretaceae, Dipterocarpaceae, Fagaceae and Leguminosae. The area occupies 6432.8 ha land between 233 and 262 masl. The

Author for Correspondence: Hari Prasad Aryal, Paklihawa Campus, Institute of Agriculture and Animal Science, Bhairahawa. Email: hahariprasadaryal06@gmail.com. 
average annual rainfall is $1391 \mathrm{~mm}$.

Phytogeographically the area lies in tropical and temperate zones embracing interesting different types of forests and soil composition. The tropical riverine belt composed of Acacia cateachu, Adina cordifolia, Anogeissus latifolius, Bombax ceiba, Dalbergia latifolia, Dalbergia sissoo, Eugeina jambolana, Mallotus philippensis, Phoenix sylvestris, Shorea robusta, Schleihera oleosa, Syzygium cumini, Tectona grandis, Terminalia alata, T. tomentosa and T. belerica etc. with an increasing altitude of Castanopsis indica, Ehretia acuminata, Leucosceptrum canum, Lithocarpus elegans, mallotus nepalensis, Quercus lamellosa, Quercus semecarpifolia, Rhododendron arboreum and Schima wallichii. The northern belt of this area has loamy sand, while the southern belt consists of sandy loam to loamy soil.

\section{MATERIALS AND METHODS}

Surveyed was done from $15^{\text {th }}$ to $31^{\text {th }}$ May and specimens were collected from $1^{\text {st }}$ June to $31^{\text {st }}$ Oct in 2011 and 2012. Mushroom samples were photographed in their natural habitat and their morphological characters were noted. Spore prints were taken. The samples were well dried and packed in wax paper bags, and wrapping with aluminums foil to prevent from the external infection as well as prevent from the intermixing of the spores, with proper tag numbers. The habitat including ecological parameters viz. altitude (by altimeter), vegetation composition, soil type, soil $\mathrm{pH}$ (by digital $\mathrm{pH}$ meter), soil moisture (by nail $\mathrm{pH}$ meter), humidity, temperatures and time (by means of thermo-Hygrometer) were recorded. The paper bags were brought to central Department of botany, Tribhuvan University, for further microscopic examination.

Some of the collected specimens were also preserved in a liquid preservative (25:5:70 $\mathrm{ml}$ rectified alcohol + formalin + distilled water), (Hawksworth et. al., 1995). The specimens were studied based on the macroscopic, microscopic and habitat characteristics. Xanthochoric reaction (Tulloss, 1994) was determined by placing a small piece of material in 5\% KOH solution, followed to the $\mathrm{NH}_{3} \mathrm{OH}$ and $\mathrm{FeSO} 4$ (Solution \& Crystal) and its colour compared with the commercial colour chart leaflet. For microscopic study the specimens were sectioned by using a sharp razor blade. The cyanophility was observed in cotton blue mounted in lactophenol reagent. The photographs were taken with a SONY DSC S980 Camera, macroscopic and microscopic characters were studied under the compound microscope, Olympus No. 575096, Tokyo (Japan), and latitude and longitude were taken by means of GPS compass.

The voucher specimens were identified with the help of relevant taxonomic literature viz.

(Singer, 1986; Kumar et al., 1990 and Watkinson et al., 2000), monograph (Gerrit, 1998) and Website (Jstor. org, Index fungorum, tropicos.org, Mycobank.org, biodiversity library.org). The voucher specimens are deposited in TUCH, Nepal.

\section{RESULTS:}

\section{Amanita volvata (Peck) Lloyd}

Amanita volvata f. avellaneosquamosa (S. Imai) E.J Gilbert, in Bresadola. Iconogr. Mycol. 27 (Suppl. 1): 304 (1941)

Local name: Besare chyau.

Taxonomic position: Basidiomycetes, Agaricales, Amanitaceae (Figure 1.1, 1.2 and 1.3)

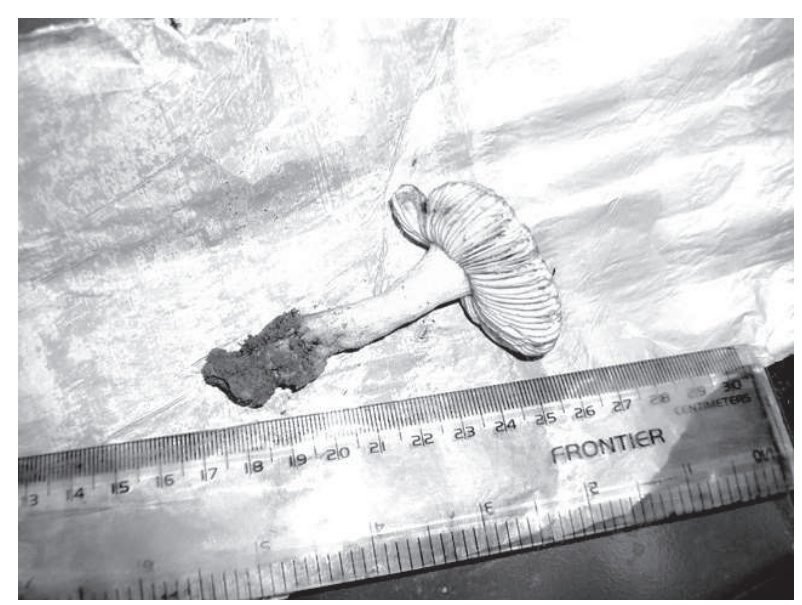

Figure 1.1: Amanita volvata

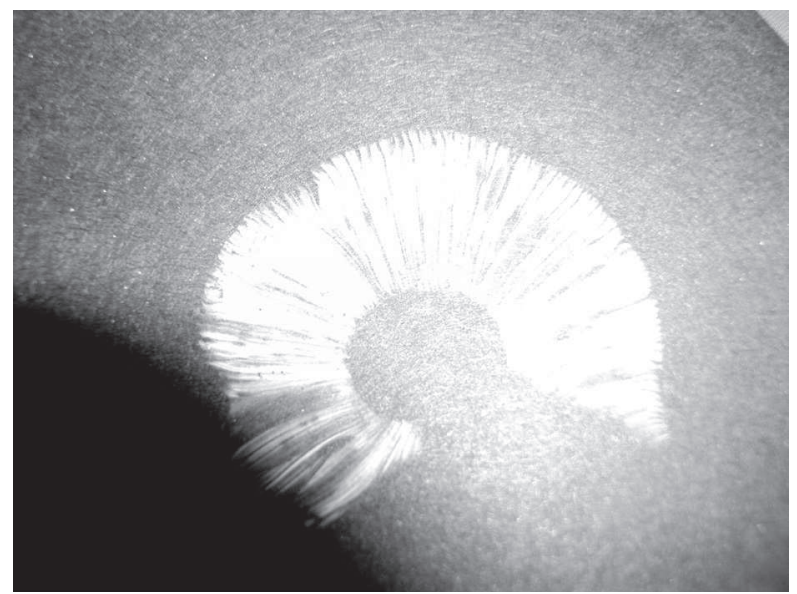

Figure 1.2: Spores print

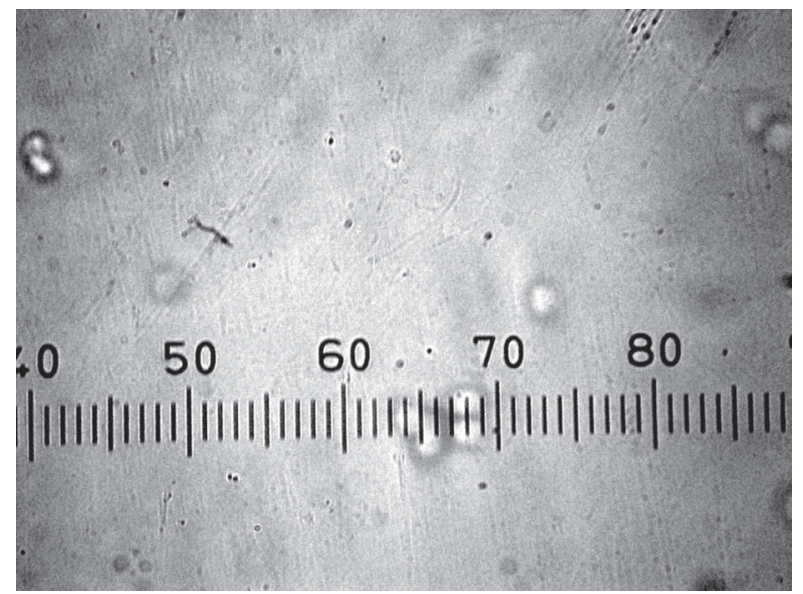

Figure 1.3: Spores $(1 \mathrm{div}=3.75 \mu \mathrm{m})$ 
Identifying characters: The species is quite rare. Absence of annulus and the presence of the large somewhat cup-shaped persistent volva. The pileus is not smooth as is usually the case in the species with a persistent membranous volva, but it is more or less scaly with minute tufts of fibrils or tomentose hairs. Sometimes the margin is not very distinctly striate. The colour varies from white to brownish. The lamellae, which are white in the fresh, in dried specimens assume a dull yellowish-brown colour, except on the edge which remains white and is more or less floccose.

Justification: Another species of A. volvaceus, Bull., has similar volva, but its spore and lamellae are pinkish or flesh-coloured and it belongs, therefore, to the subgenus Volvaria. Hence this new species $A$. volvata distinctly differed from the $A$. volvaceus.

\section{Taxonomic description:}

Pileus: $5-10 \mathrm{~cm}$ convex to flat, margin with radial striations, hairy or floccose-scaly, white to cream, pale yellow; surface often with numerous patches of thin veil remnants. Gills: free, broad, crowded; white. Stipe: $5-10$ x 1-1.5 cm, white; surface floccosescaly to powdery, also discoloring; slightly tapering upward, base emerging from a thick, membranous, fleshy, saccate volva, persistent; no ring is left on the stipe, bulbous base. Flesh: white, discolour when cut, bruised or damaged. Odor: not distinctive. Taste: not distinctive. Spores: elliptic, smooth ornamentation, cell wall thick, colour hyaline, amyloid, deposit white, cream or yellowish measurement: $9-11$ x 6-7 $\mu \mathrm{m}$ in size. Spore print: white.

Habitat: in open field, often sandy soils in mixed woods and roadsides. Rare, not common. Found in eastern North America. Ecology: Mycorrhizal. Season: JulyOctober. Edibility: Poisonous. Not edible.

Chemical reaction (Tulloss, R. E. 1994):

With $\mathrm{NH}_{3}$ :negative on all the parts.

With $\mathrm{KOH}$ : yellowish-grey on cap surface. .

With $\mathrm{FeSo}_{4}$ solution: Stipe: outer: negative \& inner: Beacon 3109, Cap: negative. Gills: Raw Silk 0351.

With $\mathrm{FeSo}_{4}$ crystal: Stipe outer: negative, inner: Beacon 3109, Cap: negative, Gills:Sandalwood 0485.

Specimen examined: Nepal, Rupandehi, Dudrachhya WN 7, 245 m, long. $27^{0} 29.3 .45^{\prime} \mathrm{N}$, lat. $083^{0} 26.4 .36^{\prime} \mathrm{E}$, Coll No. 1007123, on humus rich liter soil in Sal forest, Aryal, HP. 21.08. 2011. New to Nepal. Common

Distribution: North America and Nepal.

\section{Amanita caesarea (Scop.) Pers.}

Syn. meth.fung. (Gottingen) 2: 252 (1801)

Caesar's mushroom (Eng.)

Local name: Suntale chyau, Salle chyau, Phul chyau, Dhar shyamo (Tamang).

Taxonomic position: Basidiomycetes, Agaricales, Amanitaceae. (Figure 2.1, 2.2 and 2.3).

Taxonomic description:

Pileus: $8-20 \mathrm{~cm}$, hemispherical to flat, orange red, washing out to yellow, cuticle separable sometimes with evident membranous remains of white veil,

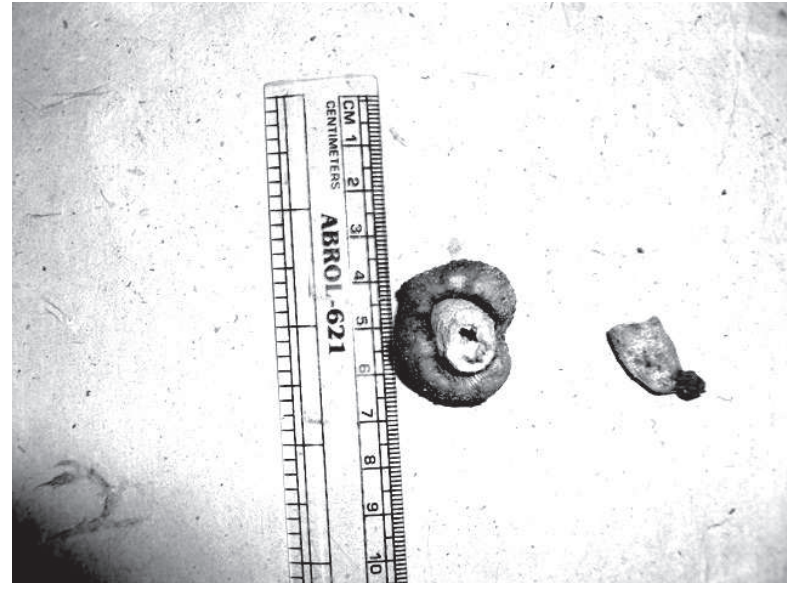

Figure 2.1: Amanita caesarea,

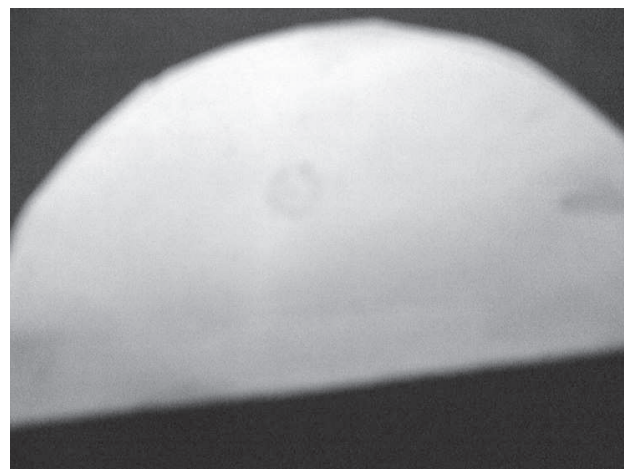

Figure 2.2: Spores print

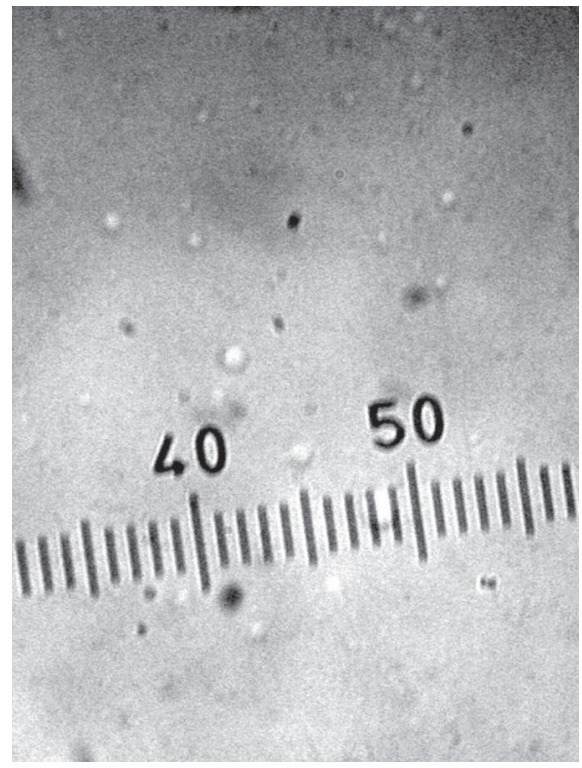

Figure 2.3: Spores $(1 \mathrm{div}=3.75 \mu \mathrm{m})$

margin striate. Gills: free, crowded, yellow. Stipe: cylindrical, 8-15 x 2-3 cm, narrowing at the top, hollow when mature, with yellow falling annulus, slightly swollen at the base, with large white membranous volva. Flesh: whitish, yellowish beneath cuticle. Odor: without evident. Taste: good. Spores: elliptical, oval to spherical, ornamentation: smooth, cell wall thick, colour hyaline, white, measurement: 8-14 x 5-8.5 $\mu \mathrm{m}$ in size. Spore print: white. 
Habitat: Soil on Quercus-Rhododendron forest. Ecology: mycorrhizal. Season: June- August.

Edibility: Edible excellent. Used as vegetable. Chemical reaction (Tulloss, R. E. 1994):

With $\mathrm{NH}_{3} \quad$ : reddish on cap surface.

With $\mathrm{KOH}$ : yellowish-grey on cap surface.

With $\mathrm{FeSo}_{4}$ solution : Stipe: outer: negative \& inner: Pale Cream 0328, Cap: negative. Gills: Ivory 0315 .

With $\mathrm{FeSo}_{4}$ crystal: Stipe: outer: negative, inner: Antique White 0940, Cap: negative, Gills: Macrame 095.

Specimen examined: Nepal, Rupandehi, Dudrachhya WN 7, 255 m, long. $27^{0} 29.4 .45^{\prime} \mathrm{N}$, lat. $083^{\circ} 26.4 .36^{\prime} \mathrm{E}$, Coll No 100755, on humus rich liter soil in Sal forest, Aryal, HP. 21.07. 2012. New to area of collection. Edible, Rs 250/Kg, Common.

\section{Previously reported:}

Manichur (Adhikari, 1976); Kathmandu market (Adhikari, 1991a); growing on soil. In moist shady place in Pinus roxburghii forest, Bajrayogini $(1600 \mathrm{~m}$, no F. 1.2.1) (Adhikari, 1991b); Kathmandu market, (Adhikari and Adhikari, 1996-97); growing on soil, in moist shady place, in Pinus roxburghii forest, Bajrayogini (1600m, no 93077) (Adhikari, 1996b); Tokha (1670m); Kakani (1790m) (Adhikari et. al., 1996); Kathmandu (Ason) market (Bhandary, 1984; Singh, 1966ab; Pandey and Budhathoki, 2002); Swayambhu and Chautara (Cotter, 1987); Nagarkot (1620m) and Tokha (1679m) (Joshi and Joshi, 1999); on soil Sundarijal (1400m), and in the Kathmandu (Ason) market. (Pandey, 2008); (Pandey et al., 2006). (Christensen et al., 2008) and Muse (Lukla) (2783m), (Rana and Giri, 2008).

Distribution: N. America, Japan, Europe, Africa, India and Nepal.

\section{Amanita chepangiana Tulloss and Bhandary}

In Mycotaxon. XLLIII (1): 235-242, 1992; Chepang slender Caesar (Eng.).

Local name Gobre musa (Che.) Salleo (Magar), Seto Kukhura phooley chyau (Nep.)

Taxonomic position: Basidiomycetes, Agaricales, Amanitaceae. (Figure 3.1, 3.2 and 3.3).

\section{Taxonomic description:}

Pileus: 13 - $19 \mathrm{~cm}$ wide, pure white, sometimes with a slight grayish to brownish or Yellowish tint over the center, convex at first later umbrella like. Gills: free, white in color close to sub crowded, white, truncate. Stipe: cylindrical, fibrillose, white, $15-18 \mathrm{~cm} \mathrm{X} 2 \mathrm{~cm}$, skirt like white annulus, just $1 \mathrm{~cm}$ below the cap, at the base

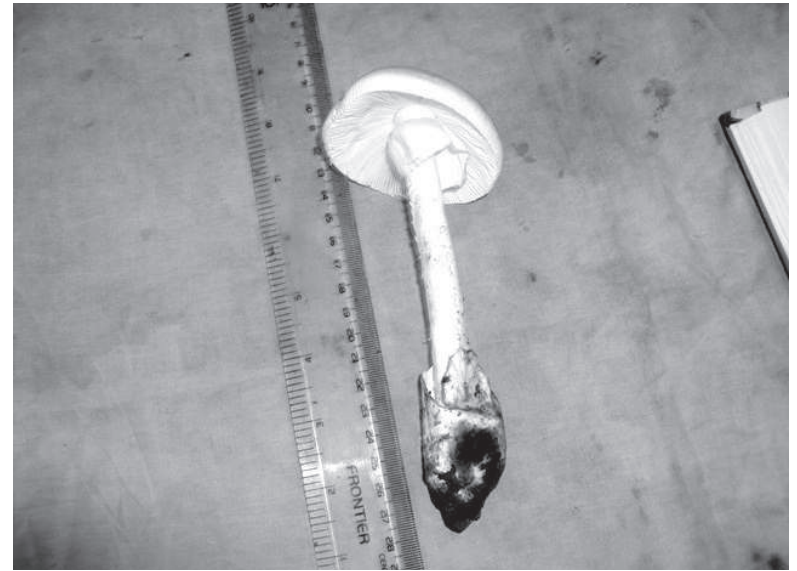

Figure 3.1: Amanita chepangiana,

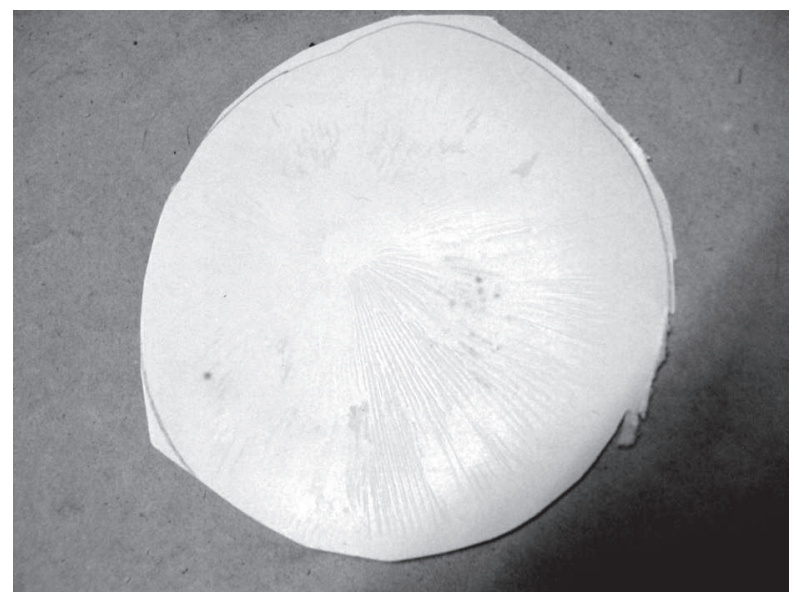

Figure 3.2: Spores print,

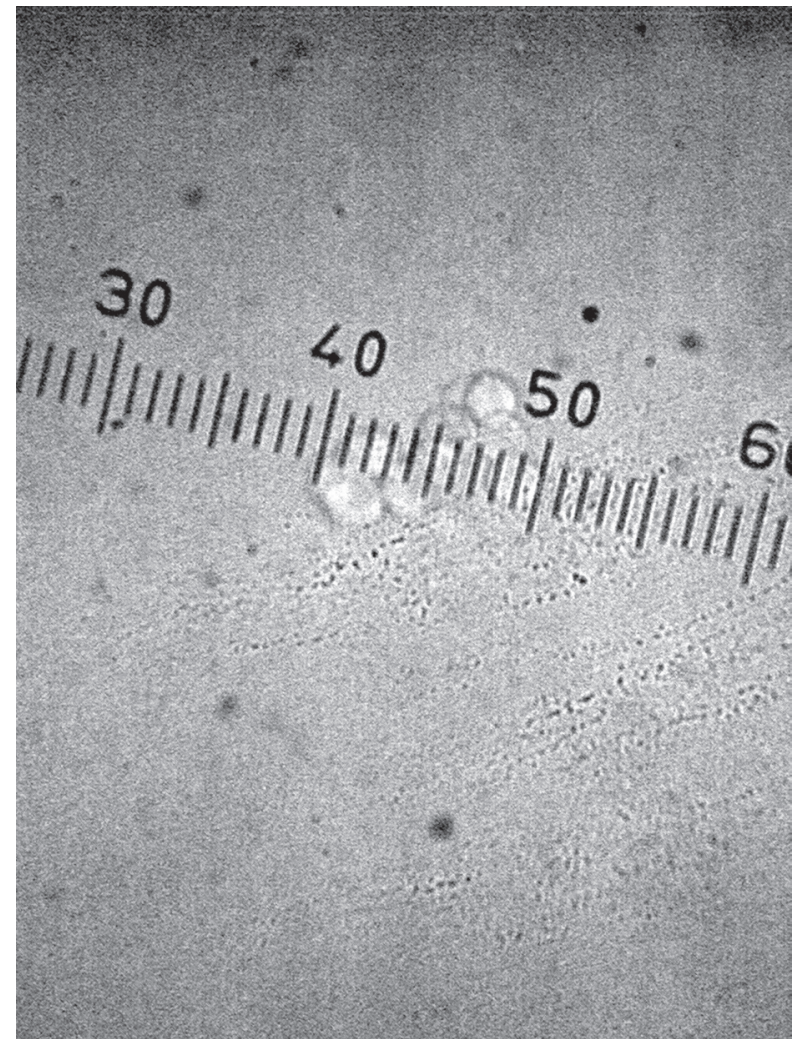

Figure 3.3: Spores $(1 \mathrm{div}=3.75 \mu \mathrm{m})$ 
large membranous volva, white, saccate. Flesh: white. Odor: none. Taste: mild. Spores: oval to subglobose, ornamentation smooth, cell wall thin, colour hyaline, inamyloid, white, measurement: 9.2 - 12.5 X 8 - $10 \mu \mathrm{m}$ in size. Spore print: white.

Habitat: Litter (debris) on the Dipterocarpaceae and Fagaceae forest. Ecology: mycorrhizal. Season: July-August. Edibility: Edible preferred by Chepang excellent. Used as vegetable.

Chemical reaction (Tulloss, R. E. 1994):

With $\mathrm{NH}_{3} \quad$ : negative on all the parts.

With $\mathrm{KOH}$ : yellow in gills.

With $\mathrm{FeSo}_{4}$ solution: Stipe: outer pale yellow \& inner Beacon 3109, Cap: yellowish. Gills:

Antique white 0940, Pileus: negative.

With $\mathrm{FeSo}_{4}$ crystal: Stipe outer pale yellow, inner sugarcane 0332, Cap: Daffodil 0308, Gills:

Suede 0N01, Pileus: negative.

Specimen examined: Nepal, Rupandehi, Parroha VDC, $233 \mathrm{~m}$, long. $27^{0} 29.2 .45^{\prime} \mathrm{N}$, lat. $083^{\circ} 26.2 .36^{\prime} \mathrm{E}$, Coll No 100772, on humus rich liter soil in Sal forest. Aryal, HP. 21.07. 2011. New to area of collection. Edible. (Rs 350/to $400 /-$ per $\mathrm{Kg}$ ). Common.

Previously reported: Jugedi, Chitwan (Tulloss and Bhandary, 1992); listed in Adhikari \& Durrieu (1996); Adhikari (2000b); on soil, Amrit Dharapani Samudayak Ban Chitwan (200m), (Pandey, 2008); listed in Christensen et al., (2008b).

Distribution: Mostly in Shorea robusta forest. Occurs in Fagaceous forest also China, South East Asia and Nepal.

\section{Amanita fulva Fr.}

Observ. Mycol. (Havniae) 1: 2 (1815)

Tawny grisette (Eng.)

Local name: Tahar shyamo (Nep.)

Taxonomic position: Basidiomycetes, Agaricales, Amanitaceae. (Figure 4.1, 4.2 and 4.3).

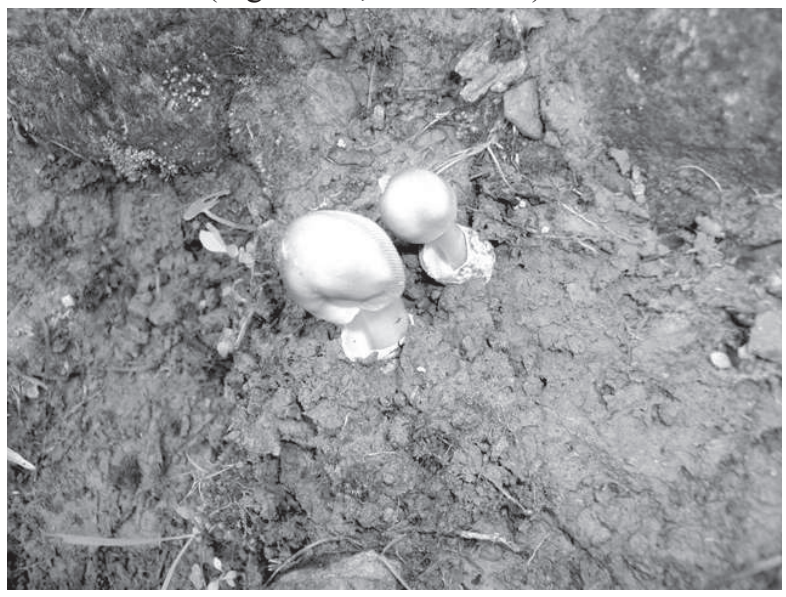

Figure 4.1: Amanita fulva,

\section{Taxonomic description:}

Pileus: grey in colour, glabrous, when mature orangebrown, paler towards the margin and darker in the center, $4-10 \mathrm{~cm}$ in diameter. It develops an umbo

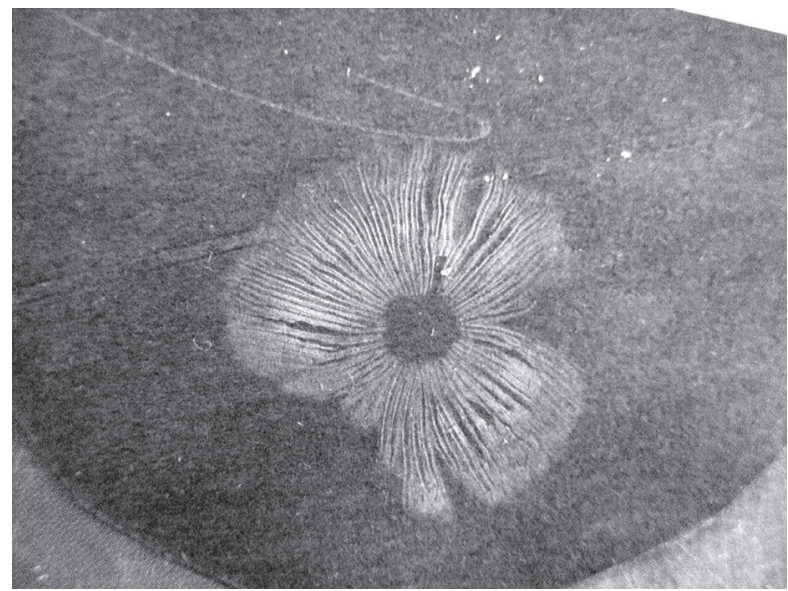

Figure 4.2:Spores print,

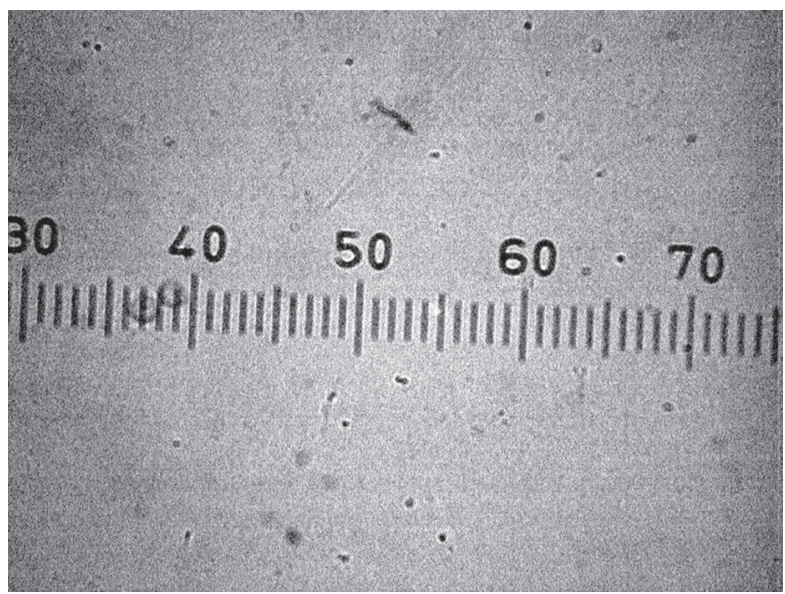

Figure 4.3: Spores $(1 \mathrm{div}=3.75 \mu \mathrm{m})$

when expanded, and has a strongly striated margin, surface is smooth, slightly sticky and slippery when moist and glistens; later it may dry, usually free of volva remnants. Infrequently, roughly polygonal pieces of the veil may remain on the surface. Gills: white, free, long, crowded. Stipe: 8-12 X 0.5-1.5 cm, white and smooth, sometimes tinged with orange-brown and with very fine hairs, slender, annulus absent, hollow and quite fragile, tapering towards the top, universal veil which initially encapsulates the fruiting body is torn and develops into a white, sack-like volva with characteristic rustybrown blemishes. Flesh: white to cream, soft. Odor: not distinctive. Taste: not distinctive. Spores: oval to spherical, ornamentation smooth somewhat hairy cell wall thick hairy appendages, colour hyaline, inamyloid, white, measurement: $8-9 \times 12-12.5$ x $9.3-12.0 \mu \mathrm{m}$ in size. Spore Print: white.

Habitat: On soil, growing along or scattered, near broad-leaved and mixed forest. Ecology: Mycorrhizal. Season: June-August. Edibility: Edible, but not popularly used (Commonly used in Gurung, Kumhal and Lodth mycophagous ethnic casts during my studies).

Chemical reaction (Tulloss, R. E. 1994):

With $\mathrm{NH}_{3}$ :negative on cap surface.

With $\mathrm{KOH}$ : negative to slightly pale yellow, on cap surface. 
With $\mathrm{FeSo}_{4}$ solution: Stipe: outer negative \& inner Bliss 0171, cap: negative. Gills: Tinge of Rose 8084 .

With $\mathrm{FeSo}_{4}$ crystal: Stipe: outer negative, inner: Pale Rose 0421, cap: negative, gills: Sugarcane 0332.

\section{Specimen examined:}

Nepal, Rupandehi, Gajedi WN 2, $262 \mathrm{~m}$, long. $27^{\circ}$ 29.5.45'N, lat. $083^{\circ}$ 26.5.36'E, Coll No 1010524, on humus rich liter soil in Sal forest, Aryal, HP. 21.06. 2011. New to area of collection. Common.

\section{Previously reported:}

Kathmandu valley (Bhandary, 1984); growing on soil, in the most shady places, in the Pinus roxburghii forest, Godawari (1515m no. 93002, 93005), Bajrayogini (1600m, no. 93075, 93085), Gokarna (no. 93097, Kakani ( $1800 \mathrm{~m}$, no. 93115), Nagarkot (1700m, no. 93044) (Adhikari, 1996a); Matatirtha (1650m), Lele (1500m), Tokha (1670m) (Adhikari et. al.,1996); in Adhikari \& Parajuli (1996); listed in Adhikari (2000b); growing on soil, in the moist shady places, in the pine forests, Phulchowki (no.9800P22) and Daman (no. 9800D52) (Adhikari and Manandhar, 2004); (Pandey et al., (2006) and Christensen et al., (2008b).

Distribution: Europe, Japan, North America and Nepal.

\section{Amanita pantherina (DC.) Kromb.}

Naturgetr. Abbild. Beschr. Schwamme (Prague): 29 (1846)

Panther mushroom, Panther cap (Eng.),

Local name: Mritu chhatrika, Manga shyamo, Bhut chyau, (Nep.).

Taxonomic position: Basidiomycetes, Agaricales, Amanitaceae. (Figure 5.1, 5.2 and 5.3).

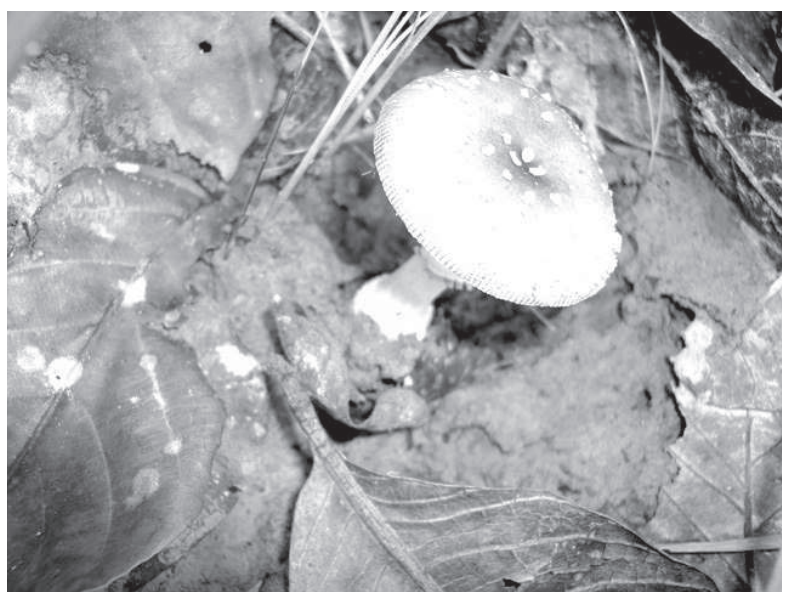

Figure 5.1: Amanita Pantherina

\section{Taxonomic description:}

Pileus: globose, then convex to expanded, $6-10 \mathrm{~cm}$ diameter, cuticle brown, covered with small white pyramidal warts, ochraceous to dark brown, striated margin. Gills: crowded, free, white. Stipe: 8-12 X 1-1.5 $\mathrm{cm}$, narrowing towards top, striated, white, with frayed, pendulous not striated white annulus, with ring-like floccose zone at the base and the strongly swollen base

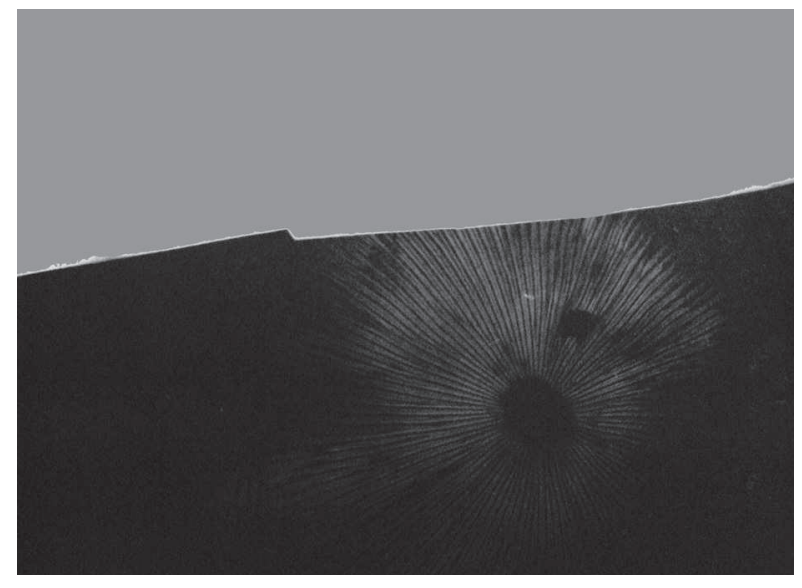

Figure 5.2:Spores print

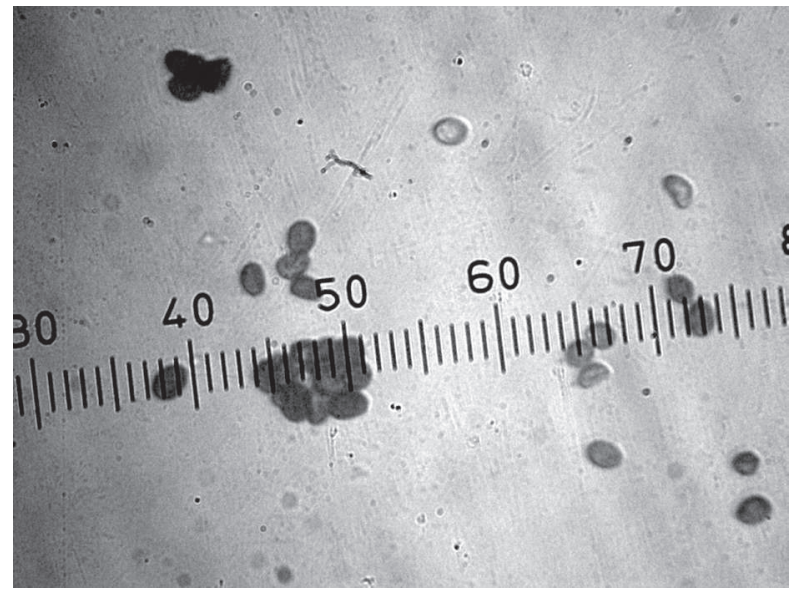

Figure 5.3: Spores (1div $=3.75 \mu \mathrm{m}$

encased in a white volva. Flesh: white, unchanging. Odor: faint, pleasant. Taste: acrid. Spores: oval to ovoid, ornamentation smooth, cell wall thick, colour hyaline, inamyloid, white, measurement: 10-12 X 7-8 $\mu \mathrm{m}$ in size. Spore print: white.

Habitat: Usually grow on near broad-leaved trees (oak, beech, birch), occasionally near coniferous trees, in broad-leaved and mixed forest. Ecology: mycorrhizal. Season: July-August. Edibility: Toxic and produce dramatic symptoms similar to those of $A$. muscaria (L.) Lam.

Chemical reaction (Tulloss, R. E. 1994):

With $\mathrm{NH}_{3} \quad$ :negative on cap surface.

With $\mathrm{KOH}$ : negative to slightly pinkish, on cap surface. With $\mathrm{FeSo}_{4}$ solution: Stipe: outer white \& inner cool Grey 6163, Cap: Marco Polo 8607, Gills:Lavender Dew 0941.

With $\mathrm{FeSo}_{4}$ crystal: Stipe outer white, inner Pale Cream 0328, Cap: Brick tone 8639, Gills: Lavender Dew 0941.

\section{Specimen examined:}

Nepal, Rupandehi, Parroha WN 9, 257 m, long. $27^{0}$ $29.59^{\prime} \mathrm{N}$, lat. $083^{\circ} 26.23^{\prime} \mathrm{E}$, Coll No 100773 , on humus rich liter soil in Sal forest, Aryal, HP. 12.08. 2011. New to area of collection. Common 
Previously reported:

On ground in forest, Phulchowki (no. 1101) Kathmandu valley (Singh and Nisha, 1976); listed in Bhandary, (1984) and Adhikari (1995); in Quercus-Rhododendron forest of Phulchowki (1780m), along with the mosses, Kakani (1700m), in mixed forest, Sundarijal (1780m) (Adhikari et al., 1996); listed in Adhikari (1996a, 2000b, 2008, 2009); in status and conservation of fungi (Adhikari, 2000a); on ground in pinus roxburghii forest, Nagarkot (1670m, no.9800111, 14.8.1998) (Adhikari and Manandhar, 2004) and place, date and collection number not mentioned, in temperate region. (Nepalese Fungi, 2004).

Distribution: North and South America, Japan, Europe, South Africa, North Asia and Nepal.

\section{DISCUSSION}

Members of this family characterized by free gills, presence of annulus and a volva; although annulus of some species disappear early (A. volvata and $A$. fulva) and volva may sometimes buried and difficult to see or may slough off. They bear white spore prints. All are mycorrhizal and their spores are hyaline and inamyloid.

Shape of the Pileus of the A. volvata is convex to flat and surface covered by numerous patches of thin veil remnants, whereas hemispherical to flat shape in A. caesarea and surface is covered by membranous remains of white veil. Similarly $A$. chepangiana has convex shape and surface is pure white and smooth and A. fulva has umbo and rough polygonal pieces of the veil on the surface. Likewise $A$. pantherina has globose and surface covered with small white pyramidal warts. Stipe is slightly tapering upwards in A. volvata, cylindrical in A. caesarea and $A$. chepangiana whereas slender in $A$. fulva and narrowing towards top in A. pantherina.

Out of five, three species viz. A. caesarea, $A$. chepangiana and A. fulva are edible. All the taxa of the genus Amanita Pers. plays an important role in forest ecology due to mycorrhizal association with vascular flora. They occur in the Shorea-Schima-CastanopsisQuercus-Rhododendron and Betula utilis forests ranging from $90 \mathrm{~m}$ to $4000 \mathrm{~m}$ in Nepal. This ectomycorrhizal fungi and its prevailing environment have not been well studied (Adhikari, 1990; Adhikari and Parajuli, 1994; Cotter, 1987).

\section{CONCLUSION}

The recent investigation created an enthusiasm towards its intensive exploration. The Amanita volvata (Peck) Lloyd is new record for Nepal. The all reported mushrooms are widely spread throughout the country in tropical to temperate belts. It needs extensive investigation to find out their morphological details, species richness, distribution pattern and species diversity index. It needs special attention to be conserved against the threat to avoid their unmanaged and unscientific exploitation. Harvesting should be done more scientifically rather than traditional methods. The mycoelements prevailing in this area need sustainable conservation and utilization.

\section{ACKNOWLEDGMENT}

I acknowledge Nepal Academy of Science and Technology to provide the research grant. Thanks are also due to Central Department of Botany, Tribhuvan University for providing the laboratory facilities. thanks to the Institute of Agriculture and Animal Science for granting my study leave. The authors are thankful to Dr. M.K. Adhikari for his cordial support. Sincere thanks are extended to local people for providing informations.

\section{REFERENCES}

Adhikari, M.K. 1976. Chyau: ek charcha (=Mushrooms: a discussion). Gorkhapatra. (Kath.).76:6. (in Nepali), (2033.8.10).

Adhikari, M.K. 1990. History of mycological explorations in Nepal. Cryptogamie Mycologie. 11: 111-128.

Adhikari, M.K.1991 a. Nepalka jangli chyauharu: Chhoto Janakari (= Wild mushrooms of Nepal: Brief introduction). Kalpavriksha. 1 (4): 4-5; Idem.2. Kalpavriksha. 1 (5): 6-8; Idem. 3. Kalpavriksha. 1 (6): 6-7; Idem.4. Kalpavriksha. 1 (7): 5-7.

Adhikari, M.K. 1991b. Notes on some higher fungi from Nepal. Journal of Natural History Museum. 12 (14): 9-18.

Adhikari, M.K. 1995.Toxic and medicinal mushrooms from Nepal. Network APINMAP/SCAMAP, Nepal. 1(1): 1-2.

Adhikari, M.K. 1996a. Biodiversite des Basidiomycetes au Nepal: etude systematique et Bio-geographique.Specialite EcologieMycologique. These du Doctorat de L'Universite present devant 1 'Universite Paul Sabatier, Toulouse, France . no.d'ordre 2309, pp. 205.

Adhikari, M.K. 1996b. New records of fleshy fungi from Kathmandu Valley. 3 Nat. Hist. Soc. Bull. 5-6 (1-4):13-15.

Adhikari, M.K. 2000a. Mushrooms of Nepal. P.U. Printers, Kathmandu, Nepal.

Adhikari MK 2000a. Mushroom of Nepal. P.U. Printers, Kathmandu, Nepal.

Adhikari, M.K. 2000b. Mushroom poisoning and its state in Nepal. Department of plant Resources, Thapathali, Kathmandu, Nepal. Bulletin of Department of Plant Resources No. 25: 36-44.

Adhikari, M.K. 2008. Nepalko parvatiyakshetraka bishalu chyauharu: chhoto jankari (=Poisonous mushrooms of hilly regions of Nepal: brief introduction). Banaspati Shrota Samachar Patra, (DPR Publication, Kathmandu). (2065). 12 (2): 4-8.

Adhikari, M.K. 2009. Researches on the Nepalese mycoflora Adhikari, K. S., Alka Basti Marga, Kathmandu, Nepal.

Adhikari, K.S. and Adhikari, M.K. 1996-1997. Collection and Consumption of wild edible mushrooms sold in Kathmandu valley. The Geographer's Point. 1-2: 1-9.

Adhikari, M.K., Adhikari, K.S., Joshi, A.R., Bhandary, R.C., Gyawali, M.B. and Pradhan, B.1996. Studies on food Value and mycotoxic wild mushrooms of Nepal submitted to APINMAP/SCAPMAP/UNESCO Committee of Nepal, Ministry of Education, Nepal, pp. 1-92. 
Adhikari, M.K. and Durrieu, G. 1996. Ethnomycologie Nepalaise. Bull. Soc. Myc. France. 112: 31-41.

Adhikari, M.K. and Parajuli, P. 1994. Mycorrhizal fungal diversity in the pine forests of Kathmandu valley, Nepal. In abstracts of the paper, Ecological Society, pp. 182-187, Kathmandu, Nepal.

Adhikari, M.K. and Parajuli P. 1996. Mycorrhizal fungal diversity in the pine forests of Kathmandu valley, Nepal: an ecological approach. Environment and biodiversity: In context to South Asia. ECOS, Kathmandu, Nepal. Pp. 182-187.

Adhikari, M.K. and Manandhar, V. 2004. Some fungi collected from Nepal. Department of plant Resources, Thapathali, Kathmandu, Nepal. Bulletin of Department of Plant Resources. 25:5-10.

.Adhikari MK, Watanabe K. 2010. New record and the revised list of mushroom genus Amanita in Nepal. Department of plant Resources, Thapathali, Kathmandu, Nepal. Bulletin of Department of Plant Resources. No.32. pp. 7-19.

Berkeley, M.J. 1838. Description of exotic fungi in the collection of Sir W. J. Hooker from memories and notes of J. F. Klotsch with addition and correction. Ans. Natural History. 3: 375-401.

Bhandary, H. R. 1984. Mushrooms. 33. In T. C. Majapuria, Nepal Nature's Paradise, Bangkok, White lotus Comp. Ltd. Pp. 235- 246.

Christensen M, Devkota S, Bhattarai S. 2008a. Use of wild edible mushrooms in the Annapurna Conservation Area, Nepal. Journal of Mycological and Phytopathological Society, Nepal. 1: 1-6.

Christensen M., Bhattrai., Devkota S. and Larsen, H.O. 2008b. Collection and use of wild edible fungi in Nepal. Eco. Bot. 62 (1):1223.

Cotter, H.V.T. 1987. The systematic and ecology of boletes with Special reference to the genus Suillus and its ectomycorrhizal relationship in Nepal. Dissertation submitted to the faculty of the Virginia Polytechnic Institute and State University in Partial fulfillment of the requirement for the degree of Ph.D. in Botany, Blacksburge, Virginia, U. S. A. pp. 175 .

Gerrit, J.K. 1998. The complete encyclopedia of Mushrooms. Rebo publisher. Pp. 286

Hawksworth, D.L., Kirt P.M., Sutton, BC. and Pegler, DN. 1995. Ainsworth and Bisby's Dictionary of Fungi ( $8^{\text {th }}$ ed.)

International Mycological institute CAB International, Wallingford, Oxon, U.K. pp. 616.
Joshi K, Joshi, AR. 1999. Ethnobotanical study of some wild mushrooms of the two valleys (Kathmandu and Pokhara) of Nepal. Ethnobotany. 11 (1 \& 2): 47- 56.

Kumar, A., Bhatt, R.P. and Lakhanpal, T.N. 1990. The Amanitaceae of India. Bishen Sing Mahendra Pal Singh, 23- A, Dehradun, India.

Lloyd, C. G. 1808. Mycological notes. Mycology. Cincinnati, Ohio: Lloyd Library \& Museum.

The News Letter on the fungal diversity of Himalayas. 2004. " Nepalese fungi.,"

Pandey, N. 2008. Mushroom Diversity in central Nepal: An ethnomycological Approach. A Doctorate thesis submitted to the Central Department of Botany, Tribhuvan University, Nepal.

Pandey, N, Budhathoki, U. 2002. Mushrooms in Relation to Different Ethnic groups of Kathmandu Valley and its Adjoining Area. Journal of basic and Applied Mycology. 2: 191-193.

Pandey, N., Devkota, S., Christensen, M., Budhathoki, U. 2006. Use of wild mushrooms among the Tamang of Nepal. Nepal journal of science and technology.7: 97-104

Rana, P. and Giri, A. 2008. Ethnomycological uses of some wild mushrooms in Sagarmatha National Park, Nepal. In: Medicinal Plants in Nepal: An Anthology of Contemporary Research. (eds. P.K.Jha, S.B. Karmacharya, M.K.Chetri, C.B.Thapa and B.B.Shrestha). Ecological Society, Kathmandu, Nepal. pp. 140-146.

Singer, R. 1986. The Agaricales in modern taxonomy. (4 ${ }^{\text {th }}$ edition), Bishen Singh Mahendra Pal Singh, Dehradun, India.

Singh, S.C. Mushrooms. Deurali (TU Stu. Mag.), 1966a. 4:13-31.

Singh, S.C. Mushrooms. Deorali. 1966b. 4: 15-31.

Singh, S.C. and Singh, N. 1976. Some fleshy fungi of Nepal. Journal of Science. 6 (1): 73-88

Tulloss, R.E. and Bhandary, H.R. 1992. Amanita Chepangiana; a new species from Nepal. Mycotaxon. XLLIII: 25- 31.

Tulloss, R. E. 1994. Seminario sobre Amanita (Supporting Materials for a Seminar on Amanita). (Univ. Autón.

Tlaxcala). $127 \mathrm{pp}$.

Watkinson, S.C., Carlile, M.C. and Gooday, G.W. 2000. The Fungi. Academic Press Limited, London, U.K. 